Article

\title{
The Role of Pulse Voltage Amplitude on Chemical Processes Induced by Streamer Discharge at Water Surface
}

\author{
Ruma ${ }^{1,+}$, Hamid Hosano ${ }^{2,3, *,+}$, Takashi Sakugawa ${ }^{2,3}$ and Hidenori Akiyama ${ }^{2,3}$ \\ 1 Department of Electrical and Electronic Engineering, Dhaka University of Engineering \& Technology, \\ Gazipur 1707, Bangladesh; ruma_duet@duet.ac.bd \\ 2 Graduate School of Science and Technology, Kumamoto University, Kumamoto 860-8555, Japan; \\ sakugawa@cs.kumamoto-u.ac.jp (T.S.); akiyama@fusiontech.jp (H.A.) \\ 3 Institute of Pulsed Power Science, Kumamoto University, Kumamoto 860-8555, Japan \\ * Correspondence: hosseini@kumamoto-u.ac.jp or hamid@kumamoto-u.ac.jp; Tel.: +81-96-342-3963 \\ + Both first authors contributed equally to this work.
}

Received: 29 March 2018; Accepted: 11 May 2018; Published: 17 May 2018

\begin{abstract}
The paper reports the effects of pulse voltage amplitude on streamer discharge propagation at water surface. The subsequent chemical processes in a reactor following the surface discharges with different voltages are presented. A pulsed power modulator (PPM) system equipped with a control unit was employed to generate $0-25 \mathrm{kV}$ pulses at $500 \mathrm{~Hz}$. A point-plane electrode configuration was used for experiments, with the point electrode placed with $1 \mathrm{~mm}$ gap from the water surface in atmospheric air, and plane ground submerged with $30 \mathrm{~mm}$ gap in water. The streamer length at water surface was significantly influenced by the pulse voltage amplitude. Colorimetric measurement of hydrogen peroxide $\left(\mathrm{H}_{2} \mathrm{O}_{2}\right)$ and treatment of indigo carmine organic dye solution were carried out to elucidate the chemical processes produced at various pulse voltages. The experimental results reveal that the applied voltage is a factor that greatly affects water surface discharges and their chemical processes.
\end{abstract}

Keywords: pulse voltage; amplitude; streamer; discharge; water surface; hydrogen peroxide $\left(\mathrm{H}_{2} \mathrm{O}_{2}\right)$; indigo carmine

\section{Introduction}

The application of high voltage pulses can generate corona or streamer discharge directly in water, or at the water's surface. Water surface discharge holds promise as a new and attractive method for environmental applications, such as the degradation of dissolved organic pollutants, sterilization of microorganisms, and the treatment of algae blooms [1,2].

Atmospheric water surface discharge reactors combine the facilities of gas phase discharge formed above the water surface with those of liquid phase discharge in water, without using supplementary gases [3,4]. In addition, these reactors enhance the liquid phase reactions through absorption of reactive species formed in the gas phase, and improve the overall efficiency of plasma chemical processes for the treatment of water $[5,6]$. Simultaneous contact between discharge plasma and gas and liquid molecules becomes possible with this method.

After initiation at the high voltage (H.V.) electrode tip, discharges directly propagate through the gas phase, and spread radially over the water surface within a very short period (several nanoseconds). During propagation, discharges initiate various physical and chemical phenomena that result in high energy-electrons, UV light emission, shockwaves, and the formation of a variety of reactive radicals $\left(\mathrm{OH}^{\bullet}, \mathrm{O}^{\bullet}, \mathrm{H}^{\bullet}, \mathrm{HO}_{2}^{-}\right)$, ions $\left(\mathrm{H}^{+}, \mathrm{O}^{-}, \mathrm{H}_{3} \mathrm{O}^{+}\right)$, and molecular species $\left(\mathrm{H}_{2}, \mathrm{O}_{2}, \mathrm{O}_{3}, \mathrm{H}_{2} \mathrm{O}_{2}\right)$ in gas, at the 
gas-liquid interface, and in liquid [2-14]. Primary radicals or ions are expected to be generated in gas, or at the interface, and then injected into the water, which subsequently reacts to form secondary molecular species. Among these active species, $\mathrm{OH}^{\bullet}$ radicals, $\mathrm{H}_{2} \mathrm{O}_{2}$ and $\mathrm{O}_{3}$ contribute greatly to the degradation of organic pollutants, due to their high oxidizing power. The oxidation power of $\mathrm{OH}^{\bullet}$ radicals, atomic oxygen, ozone, and hydrogen peroxide are 2.80, 2.42, 2.07 and 1.78, respectively [8].

The activity of these species has been reported for effective degradation of many organic compounds, including phenols [3,4,15], indigo carmine [16,17], acid orange [18], 4-chlorophenol, 3,4-dichloroaniline, 2,4,6-trinitrotolune [19,20], rhodamine B [21], and methylene blue [22]. Different studies have shown possible chemical reactions related to the formation of these species by pulsed streamer discharge in air, directly in water, or at the air-water interface, as [5-9,12-14,23-28]:

$$
\begin{gathered}
\mathrm{O}_{2}+\mathrm{e}^{-} \rightarrow 2 \mathrm{O}^{\bullet}+\mathrm{e}^{-} \\
\mathrm{O}^{\bullet}+\mathrm{O}_{2} \rightarrow \mathrm{O}_{3} \\
\mathrm{H}^{\bullet}+\mathrm{O}_{3} \rightarrow \mathrm{OH}^{\bullet}+\mathrm{O}_{2} \\
\mathrm{O}^{\bullet}+\mathrm{H}_{2} \mathrm{O} \rightarrow 2 \mathrm{OH}^{\bullet} \\
\mathrm{H}_{2} \mathrm{O}+\mathrm{e}^{-} \rightarrow \mathrm{H}_{2} \mathrm{O}^{+}+2 \mathrm{e}^{-} \\
\mathrm{H}_{2} \mathrm{O}^{+}+\mathrm{H}_{2} \mathrm{O} \rightarrow \mathrm{OH}^{\bullet}+\mathrm{H}_{3} \mathrm{O}^{+} \\
\mathrm{H}_{2} \mathrm{O}+\mathrm{e}^{-} \rightarrow \mathrm{H}^{\bullet}+\mathrm{OH}^{\bullet}+\mathrm{e}^{-} \\
\mathrm{OH}^{\bullet}+\mathrm{OH}^{\bullet} \rightarrow \mathrm{H}_{2} \mathrm{O}_{2} \\
\mathrm{OH}^{\bullet}+\mathrm{H}_{2} \mathrm{O}_{2} \rightarrow \mathrm{H}_{2} \mathrm{O}+\mathrm{HO}_{2} \\
\mathrm{H}^{\bullet}+\mathrm{HO}_{2} \rightarrow \mathrm{H}_{2} \mathrm{O}_{2} \\
\mathrm{H}_{2} \mathrm{O}_{2}+\lambda v \rightarrow \mathrm{OH}^{\bullet}+\mathrm{H}^{\bullet}+\mathrm{O}^{\bullet}
\end{gathered}
$$

Various parameters, such as electrode configuration, electrode gap, pulse frequency, applied voltage, pulse width, $\mathrm{pH}$ value, medium pressure, and solution conductivity strongly influence the physical and chemical processes of discharge. Production efficiency of these species and their degradation processes primarily depend on the conditions of applied voltage pulse to the reactor. Thus, elucidation of relations of applied pulse voltage with species formation by streamer processes at water surface is of great interest, because applied pulse voltage conditions determine the decontamination efficiency of the discharge reactor. Akishev et al. studied the development of a plasma sheet structure in a surface dielectric barrier discharge powered with a single long pulse of negative polarity, and showed the effect of pulse amplitude and duration on the development of streamers and leaders in $\mathrm{Ar}$ gas at atmospheric pressure [29]. Miyahara et al. reported that positive streamers were stronger and longer than those of negative polarity; they also showed that the concentration of $\mathrm{H}_{2} \mathrm{O}_{2}$ was increased with positive polarity of the applied voltage [30]. Previous studies showed effects of voltage amplitude applied directly in water on both the discharge processes and treatment of polluted water [9-12]. However, water surface discharges and their plasma induced chemical processes for different pulse widths and peak voltages have not been sufficiently studied.

The main purpose of the present study is to investigate the effects of pulse voltage amplitude on the chemical process of streamer discharge at the water's surface. An all solid-state pulsed power modulator (PPM), using a magnetic pulse compression (MPC) circuit designed for water discharge, was employed to generate high voltage pulses. A control unit was connected to the PPM system to accurately regulate the output high voltage pulses. The physical appearance of streamers at water surface, and quantitative measurements of hydrogen peroxide $\left(\mathrm{H}_{2} \mathrm{O}_{2}\right)$ in water with variation 
of applied pulse voltage, are reported. $\mathrm{H}_{2} \mathrm{O}_{2}$ is a basic indicator of $\mathrm{OH}^{\bullet}$ radicals, and is formed primarily by recombination of $\mathrm{OH}^{\bullet}$ radicals in the discharge region [13]. It has a relatively long lifetime, while $\mathrm{OH}^{\bullet}$ radicals, $\mathrm{O}_{3}$, and other species have a very short-lifetime (a few nano-seconds to micro-seconds) [14]. The paper also presents degradation of indigo carmine organic dye results, as a model pollutant to evaluate effects of pulse voltage on the chemical processes following the water surface discharge.

\section{Experimental Methods}

A schematic of the experimental setup is shown in Figure 1. A high voltage point electrode was placed in atmospheric air at $1 \mathrm{~mm}$ from the water surface; a plane ground ( $\mathrm{Al}, 40 \mathrm{~mm}$ diameter) was immersed in the water $30 \mathrm{~mm}$ from the surface. A pulsed power modulator (PPM) consisting of a magnetic pulse compression (MPC) circuit was used as the high voltage source, with its output voltage controlled by a control unit (designed in our group and manufactured by Suematsu Electronic Co., Tokyo, Japan). A charger unit was implemented to supply DC power to the control unit and the PPM system. The control unit consisted of variable resistors and integrated circuits (ICs), through which the output voltage of the PPM system could be controlled. A V-program of the control unit was connected to variable resistors to regulate them linearly, from $0-100 \%$. In this work, we varied the applied voltage amplitude to the reactor at $9.1,11.6,14.0,16.5$, and $21.6 \mathrm{kV}$, by setting V-program at $50 \%, 60 \%, 70 \%$, $80 \%$, and $100 \%$ of the variable resistors. The pulse repetition frequency was $500 \mathrm{~Hz}$. The water solution consisted of distilled water and $\mathrm{KCl}$, prepared at $100 \mu \mathrm{s} / \mathrm{cm}$, and measured by a conductivity meter (CD5021A, Custom). A water jacket glass reactor of $200 \mathrm{~mL}$ volume was used. Electrical measurement was performed using a digital oscilloscope (DPO4054B, Tektronix, Beaverton, OR, USA) equipped with a high voltage probe (P6015A, Tektronix, USA) and a current monitor (model no. 3972, Pearson, Palo Alto, CA, USA). Discharge energy was calculated by integrating the instantaneous product of voltage and current waveforms. Discharge propagation at water surface was captured using a high-speed video camera (VW-6000, Keyence, Japan) and an ultra-high-speed framing camera with $5 \mathrm{~ns}$ exposure and $5 \mathrm{~ns}$ inter-frame time (Ultraneo, Nac, Japan).

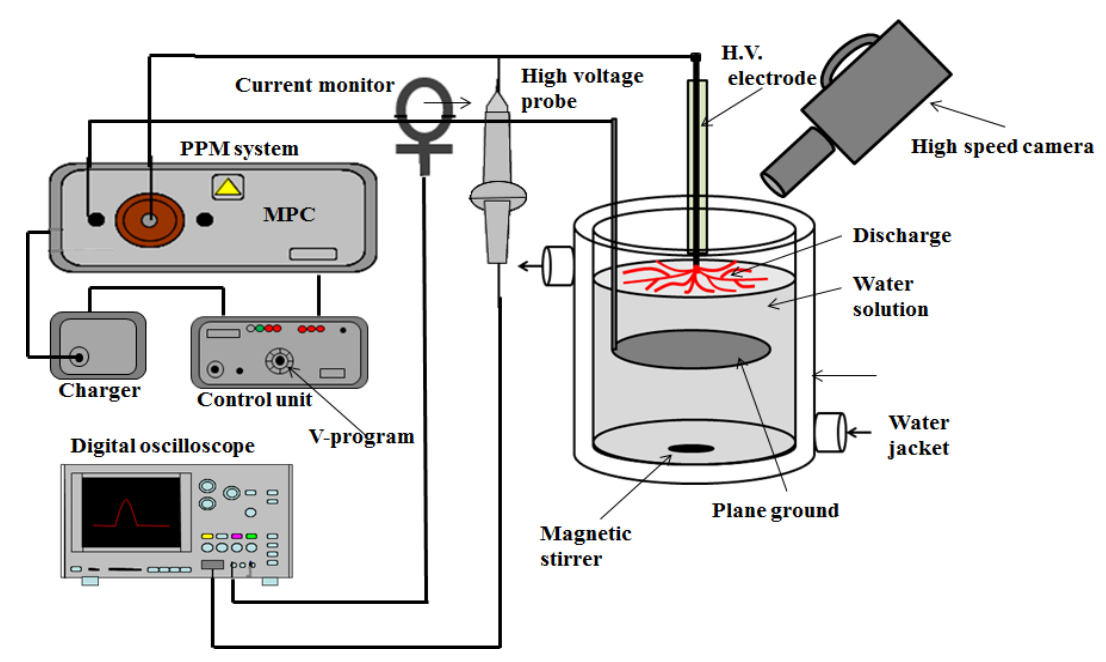

Figure 1. Schematic of the experimental setup to generate and evaluate the water surface discharge.

The colorimetric method was used to measure the concentration of $\mathrm{H}_{2} \mathrm{O}_{2}$ generated by this process. The concentration of $\mathrm{H}_{2} \mathrm{O}_{2}$ was measured in mmol, using a spectrophotometer (U-2900, Hitachi High-Technologies, Japan) at $410 \mathrm{~nm}$ spectrum. In this method, $2 \mathrm{~mL}$ of the discharge sample water was added to $1 \mathrm{~mL}$ of titanium sulfate $\left(\mathrm{TiSO}_{4}\right)$ reagent, which yielded a yellow color pertitanic acid complex $\left(\mathrm{H}_{2} \mathrm{TiO}_{4}\right)$ at absorbance $\lambda=410 \mathrm{~nm}$, indicating the formation of $\mathrm{H}_{2} \mathrm{O}_{2}$ [28]. An indigo carmine $\left(\mathrm{C}_{18} \mathrm{H}_{8} \mathrm{~N}_{2} \mathrm{Na}_{2} \mathrm{O}_{8} \mathrm{~S}_{2}\right.$, molecular weight $\left.466.36 \mathrm{~g} / \mathrm{mol}\right)$ dye solution was prepared 
by dissolving $30 \mathrm{mg}$ of dye powder in $1 \mathrm{~L}$ of deionized water. UV-visible absorption spectra were measured ( $3 \mathrm{~mL}$ dye sample) before and after pulse treatments, using the same spectrophotometer in 200-800 nm wavelengths.

\section{Results and Discussion}

Typical images of streamer discharge at water surface at different applied voltages are shown in Figure 2. The images were captured by the high-speed video camera at $40 \mu \mathrm{s}$ exposure time. The discharge is characterized by streamer branching at the water surface with variation of pulse voltage. Streamer lengths varied from $15 \mathrm{~mm}$ to $32 \mathrm{~mm}$, with an increasing voltage amplitude from 9.1 to $21.6 \mathrm{kV}$, as shown in Figure 3. The light emission from the streamer was brighter at increased voltages. For a clear understanding of streamer development at different voltages, we observed streamers using the ultra-high-speed framing camera.

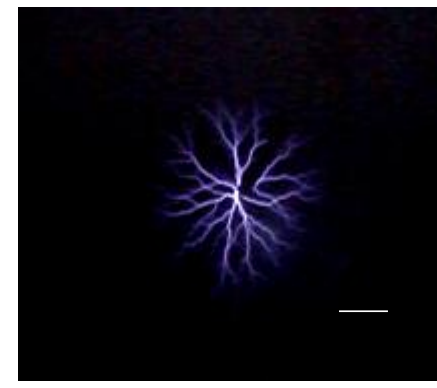

(a)

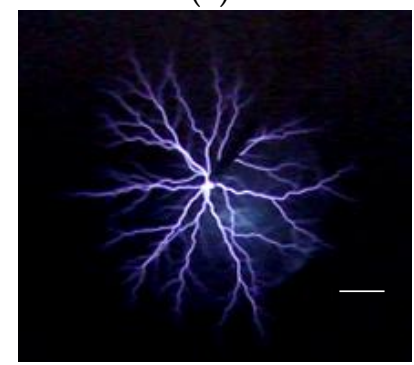

(d)

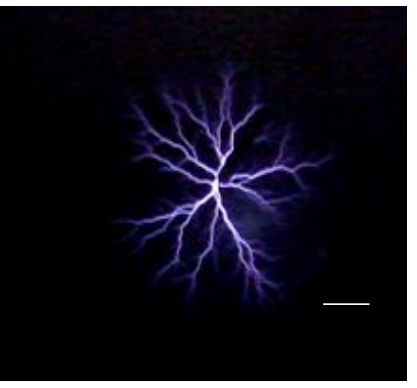

(b)

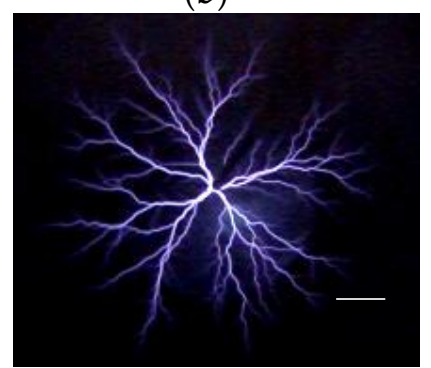

(e)

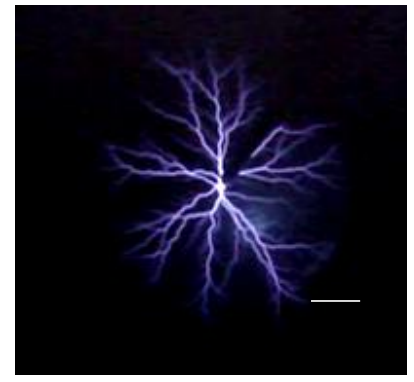

(c)

Figure 2. Images of streamer discharges at water surface captured by using a high speed video camera at applied voltages of (a) 9.1; (b) 11.6; (c) 14.0; (d) 16.5; and (e) $21.6 \mathrm{kV}$ (scale bar = $5 \mathrm{~mm}$ ).

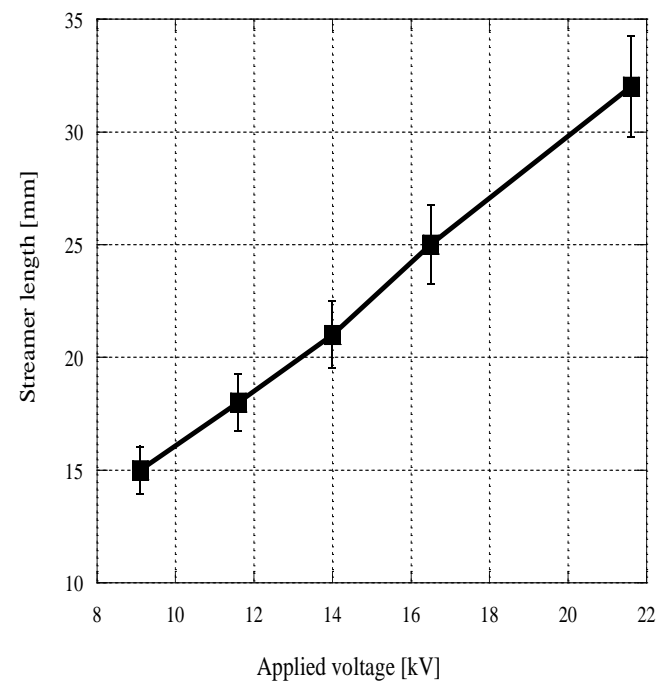

Figure 3. Variation of streamer length at water surface with applied pulse voltage. 
Figure 4 shows real-time images (four selected frames from twelve frames) at $11.6 \mathrm{kV}$ and $21.6 \mathrm{kV}$, with $150 \mathrm{~ns}$ and $50 \mathrm{~ns}$ exposure time, respectively, and a $250 \mathrm{~ns}$ inter-frame time in both cases. All streamer channels were initiated at the H.V. electrode tip in air, directly crossing the air gap, then expanding near the water surface, and finally spreading over the surface with several thin branch channels. The propagation and full development of streamers was faster at $21.6 \mathrm{kV}$ than at $11.6 \mathrm{kV}$. The calculated propagation velocities of streamer heads on the water surface were $74.64 \mathrm{~km} / \mathrm{s}$ for $11.6 \mathrm{kV}$, and $167.15 \mathrm{~km} / \mathrm{s}$ for $21.6 \mathrm{kV}$. Meanwhile, the propagation velocity across the air gap was much faster, and could not be measured, even with a $5 \mathrm{~ns}$ inter-frame visualization. Also, the expansion gap of the streamer branches near the water surface was larger at $11.6 \mathrm{kV}$ than at $21.6 \mathrm{kV}$. These results suggest that a strong electric field concentrated at the H.V. electrode tip released higher energy electrons, and caused faster streamer propagation at higher voltages. Previous studies have demonstrated that the velocity and mode of propagation of the streamer depends on the electric field, which in turn is a function of the applied voltage, with higher voltage levels leading to a reduced time of breakdown in streamer formation [31,32]. For underwater discharge, it has been shown that an increase in peak high voltage results in a higher velocity of streamer propagation [1], an increase in streamer length [12], and a reduction of streamer development time [31].

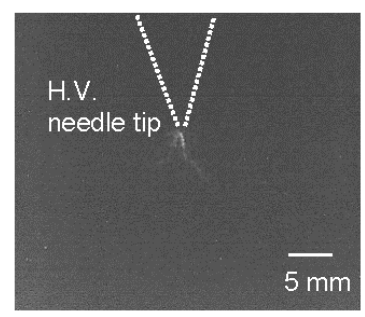

a(i) $0 \mathrm{~ns}$

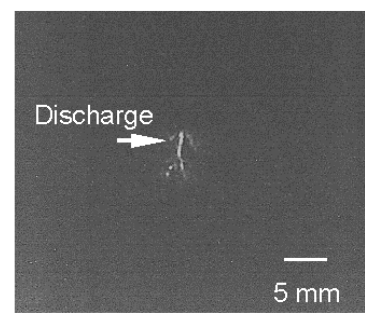

b(i) $0 \mathrm{~ns}$

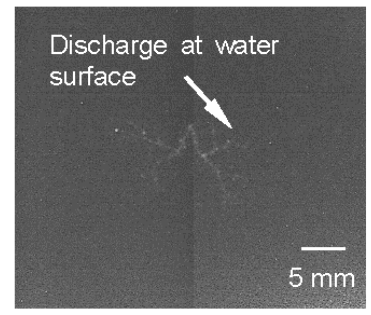

a(ii) $250 \mathrm{~ns}$

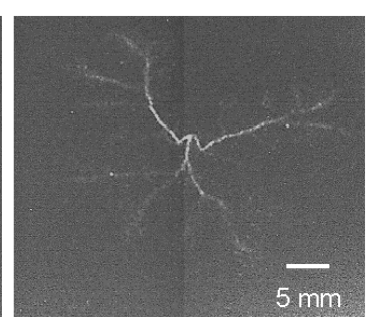

b(ii) $250 \mathrm{~ns}$

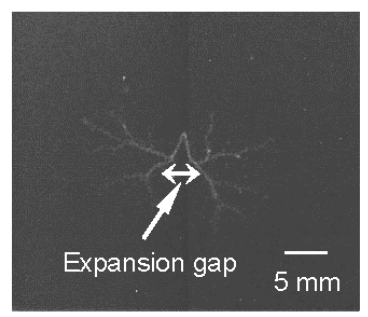

a(iii) $500 \mathrm{~ns}$

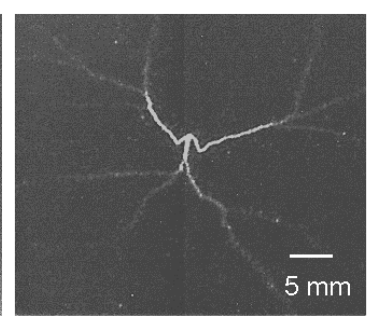

b(iii) $500 \mathrm{~ns}$

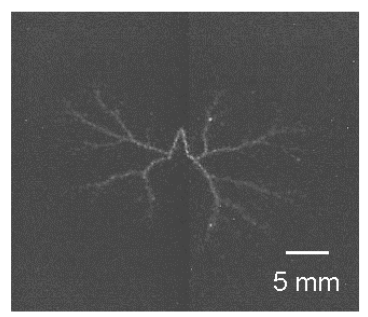

a(iv) $750 \mathrm{~ns}$

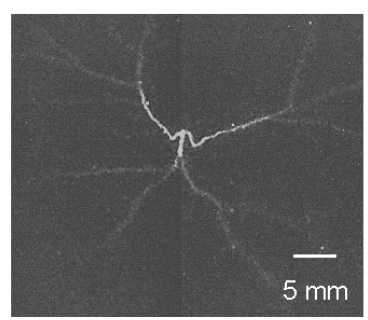

b(iv) $750 \mathrm{~ns}$

Figure 4. Real-time images of streamer captured by an ultra-high speed framing camera at applied voltage of $(\mathbf{a}(\mathbf{i}-\mathbf{i v})) 11.6 \mathrm{kV}$, exposure time $150 \mathrm{~ns}$; and $(\mathbf{b}(\mathbf{i}-\mathbf{i v})) 21.6 \mathrm{kV}$, exposure time $50 \mathrm{~ns}$; inter-frame rate $250 \mathrm{~ns}$ for both cases (scale bar $=5 \mathrm{~mm}$ ).

Waveforms of load voltage and current during discharge at 9.1 and $21.6 \mathrm{kV}$ are shown in Figure $5 \mathrm{a}, \mathrm{b}$. An increase of the voltage amplitude results in an increase in the peak value of current. The pulse width of both voltage and current waveforms were decreased with an increase of applied voltage. Peak values of corresponding currents were 2.3, 4.0, 5.4, 7.5, and $12.9 \mathrm{~A}$, and their respective pulse widths were $2.53,1.76,1.36,1.32$, and $1.18 \mu \mathrm{s}$, for applied voltages of 9.1, 11.6, 14.0, 16.5, and $21.6 \mathrm{kV}$, respectively. The V-program changed the variable resistance of the control unit; thus, the total resistance of the control circuit adjusted to each new value, which subsequently influenced the PPM output pulse.

Effects of voltage amplitude on hydrogen peroxide $\left(\mathrm{H}_{2} \mathrm{O}_{2}\right)$ formation for pulsed streamer discharge at water surface are shown in Figure 6. These results show that $\mathrm{H}_{2} \mathrm{O}_{2}$ concentration at $21.6 \mathrm{kV}$ is higher than that of the other applied voltages $(9.1,11.6,14.0$, and $16.5 \mathrm{kV})$. A possible reason is that increase of branches and velocities of the streamer heads with increases of applied voltage may influence the chemical reaction at the discharge region. Thus, at $21.6 \mathrm{kV}$, a maximum 
possible amount of vapor or water molecules at the water surface comes into contact with the discharge plasma due to increased streamer volume, resulting in a large amount of $\mathrm{OH}^{\bullet}$ radicals at the air-water interface, or at the water surface. These are then inserted into the water, initiating further reactions with water molecules, and their subsequent recombination to provide more $\mathrm{H}_{2} \mathrm{O}_{2}$ in the water. As radical generation primarily depends on plasma contact area, electron energy diffused from the H.V. electrode tip relates to excitation and dissociation of water molecules $[13,14]$.

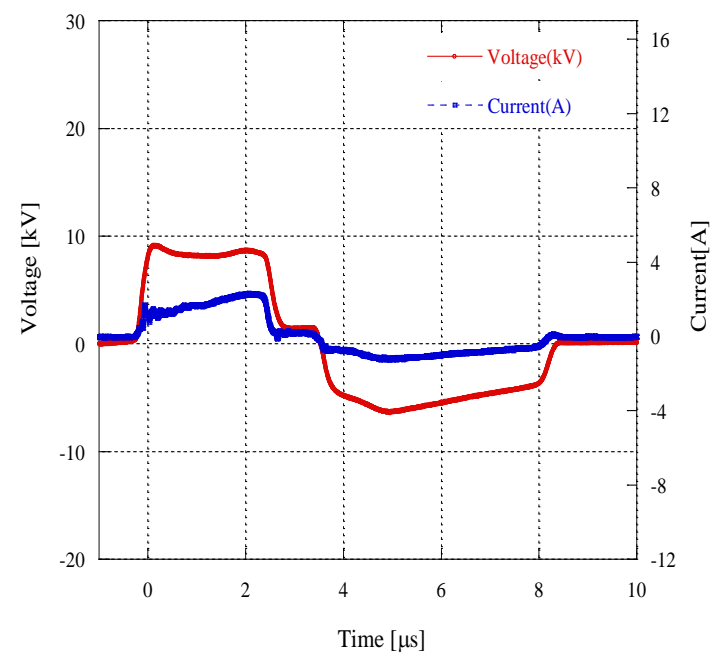

(a)

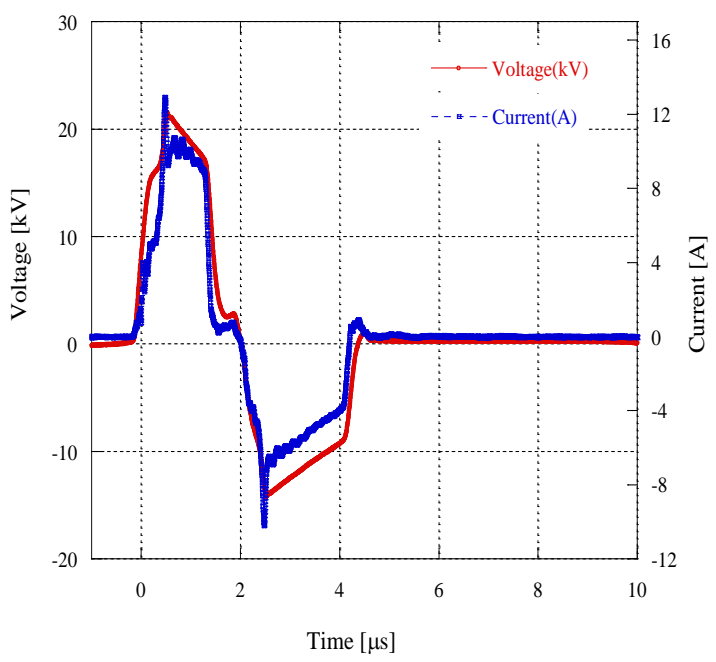

(b)

Figure 5. Typical waveforms of voltage and current measured at (a) $9.1 \mathrm{kV}$ and (b) $21.6 \mathrm{kV}$ during discharge at water surface.

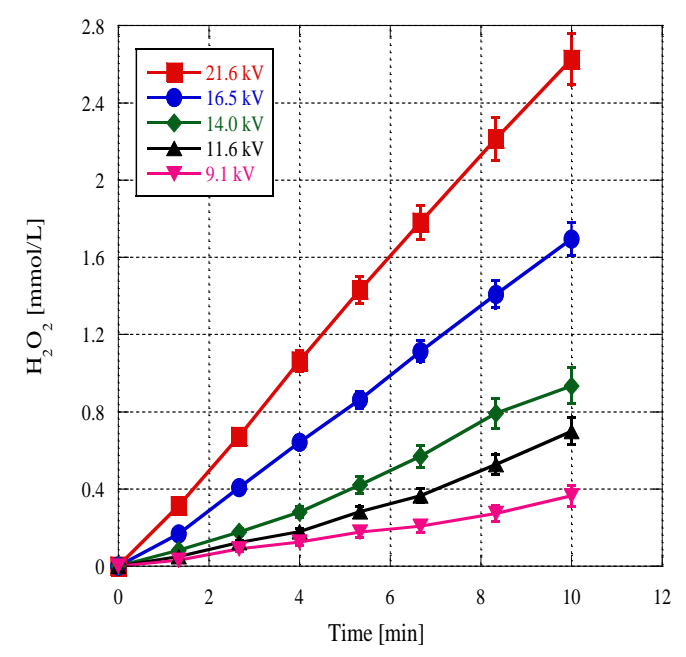

Figure 6. Production of hydrogen peroxide $\left(\mathrm{H}_{2} \mathrm{O}_{2}\right)$ for different voltage amplitudes of streamer discharge at water surface.

In our experiments, the gap distance between the H.V. electrode tip and the water surface was maintained at $1 \mathrm{~mm}$, thus facilitating diffusion of other short live species $\left(\mathrm{O}^{\bullet}, \mathrm{H}^{\bullet}, \mathrm{HO}_{2}{ }^{-}, \mathrm{O}_{3}\right)$ in the water, as well as the production of $\mathrm{OH}^{\bullet}$ radicals via various types of chemical reactions. In addition, the energy consumed by the discharge was higher at $21.6 \mathrm{kV}$ than that at other applied voltages; their amounts varied, at $0.059,0.112,0.141,0.228$, and $0.322 \mathrm{~J} /$ pulse, for $9.1,11.6,14.0,16.5$, and $21.6 \mathrm{kV}$, respectively. Therefore, at $21.6 \mathrm{kV}$, high-energy electrons from the H.V. electrode tip could be directly injected to the surface to dissociate water molecules and produce a greater amount of the active species. Meanwhile, the $\mathrm{pH}$ and conductivity of the solution increased with time (i.e., the number of pulses), 
as shown in Figure 7. On the other hand, the change of $\mathrm{H}_{2} \mathrm{O}_{2}$ concentration from 9.1 to $14.0 \mathrm{kV}$ was not significant, which could be related to the applied energy per pulses.

It has been reported that the concentration of $\mathrm{OH}^{\bullet}$ increases with increasing peak voltage, and that $\mathrm{OH}^{\bullet}$ may be produced in humid air [9] or in air bubbling water [23] by discharge. To find out the effect of nitrogen oxide or nitrogen product on the formation of $\mathrm{H}_{2} \mathrm{O}_{2}$ in our system, we conducted experiments with the same conditions, added sodium azide $\left(\mathrm{NaN}_{3}\right)$, and measured the $\mathrm{H}_{2} \mathrm{O}_{2}$ concentration. The addition of $\mathrm{NaN}_{3}$ had no effect on $\mathrm{H}_{2} \mathrm{O}_{2}$ concentration (changes were within error bars). While we could smell ozone in the air during the experiments, we could not measure ozone in the reactor, as we only measured $\mathrm{H}_{2} \mathrm{O}_{2}$ in the water, as it is a stable molecular species.

Production yield efficiency of $\mathrm{H}_{2} \mathrm{O}_{2}$ increased with voltage amplitude (pulse energy), as shown in Figure 8. The reaction rate constant $\left(\mathrm{k}_{\mathrm{H} 2 \mathrm{O} 2}\right)$ was determined from a curve fit of Figure 6; it was 0.56, $1.21,1.61,2.88$, and $4.44\left(\times 10^{-6} \mathrm{~mol} /(\mathrm{L} \cdot \mathrm{s})\right)$ for applied voltages of $9.1,11.6,14.0,16.5$, and $21.6 \mathrm{kV}$, respectively. When the voltage amplitude was set to $21.6 \mathrm{kV}$, strong streamers were developed with high velocities at longer lengths; they also consumed more energy per pulse. Thus, strong plasma chemical reactions took places at the discharge-water contact region. Therefore, more water molecules came into contact with high energy electrons, resulting in extra amounts of active species, which caused a higher reaction rate constant at $21.6 \mathrm{kV}$ than at other voltage amplitudes.

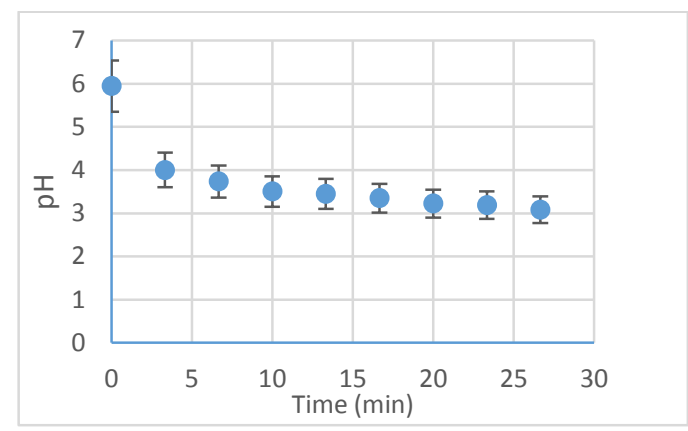

(a)

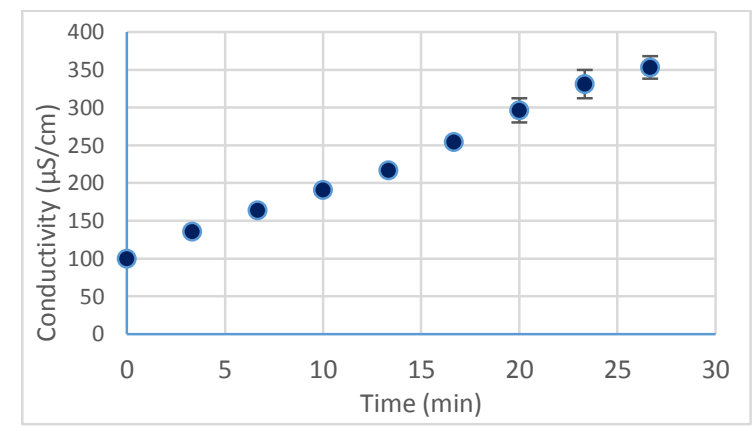

(b)

Figure 7. Variation of $\mathrm{pH}(\mathbf{a})$ and conductivity (b) of the discharge solution with time at $21.6 \mathrm{kV}$ voltage amplitude.

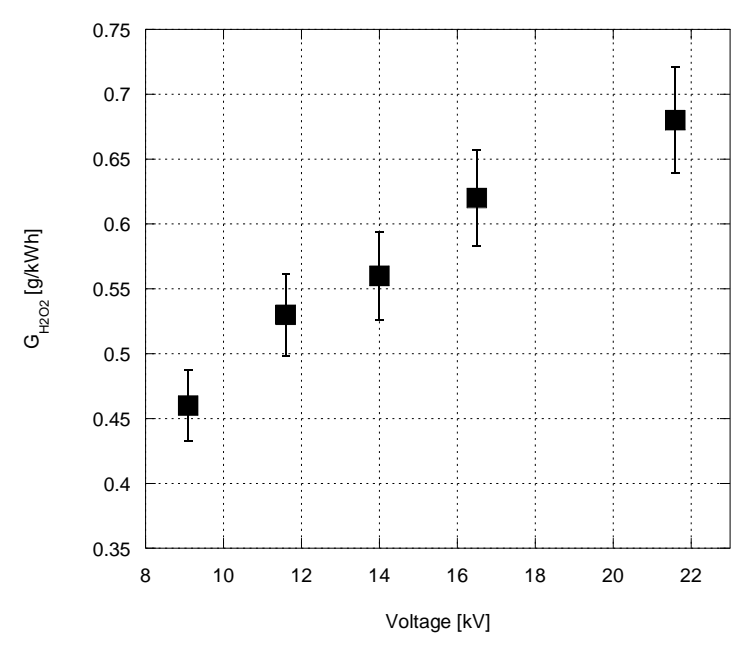

Figure 8. Production yield efficiency of $\mathrm{H}_{2} \mathrm{O}_{2}\left(\mathrm{G}_{\mathrm{H} 2 \mathrm{O} 2}\right.$ in $\left.\mathrm{g} / \mathrm{kWh}\right)$ for different voltage amplitudes of streamer discharge plasma at water surface.

To confirm the results and clarify the role of voltage amplitude on water surface streamer discharge, we treated an Indigo carmine (IC) organic dye solution as a polluted water sample. 
Indigo carmine $\left(\mathrm{C}_{18} \mathrm{H}_{8} \mathrm{~N}_{2} \mathrm{Na}_{2} \mathrm{O}_{8} \mathrm{~S}_{2}\right)$ consists of a chromogenic bond of a single $\mathrm{C}=\mathrm{C}$ double bond substituted by two $\mathrm{NH}$ donor groups, with two $\mathrm{C}=\mathrm{O}$ acceptor groups at the center of the formula $[16,24,33-35]$. The unsaturated bond is a double bond of carbon in a benzene ring, and the center of the formula of indigo carmine [23,24].

The temporal changes of UV-visible spectra of the dye solution before and after treatment are shown in Figure $9 a, b$ for 9.1 and $21.6 \mathrm{kV}$ of pulse voltage amplitudes. The treatment time was only $7.5 \mathrm{~min}$. Figure $9 \mathrm{a}, \mathrm{b}$ indicates that there was a strong absorbance peak of the dye solution at $610 \mathrm{~nm}$, and that this decreased abruptly with treatment at $21.6 \mathrm{kV}$, compared with that of $9.1 \mathrm{kV}$. The dye color changed to almost transparent after 6.0 min of surface discharge treatment at $21.6 \mathrm{kV}$, which was significantly different from the treatment at $9.1 \mathrm{kV}$. These results indicate that the strong chromogenic $\mathrm{C}=\mathrm{C}$ double bond, which is mainly responsible for the blue color of dye solution, is broken rapidly due to contact of discharge plasma at water surface.

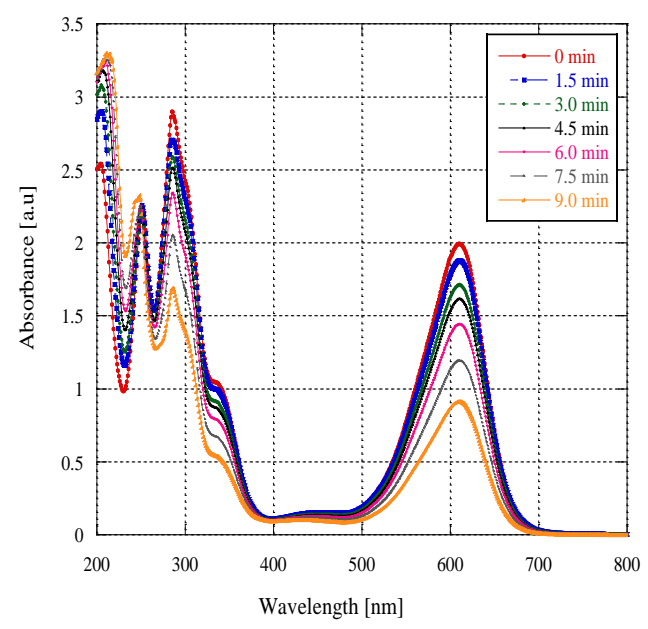

(a)

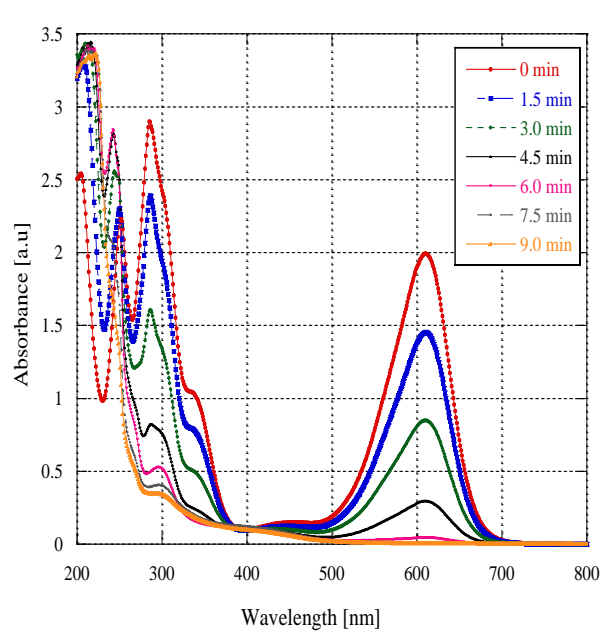

(b)

Figure 9. Temporal change of UV-visible spectra of indigo carmine dye solution after $7.5 \mathrm{~min}$ at (a) $9.1 \mathrm{kV}$ and (b) $21.6 \mathrm{kV}$ of applied voltage pulse treatment at water surface.

Decoloration of different dyes were studied by pulsed high voltage discharge plasma over the water surface under an argon atmosphere in a batch type reactor, and shown to be effective [36]. The $\mathrm{C}=\mathrm{C}$ bonds of the indigo carmine molecule were found to be very reactive to $\mathrm{OH}^{\bullet}$ or $\mathrm{O}^{\bullet}$ radicals [24,25], and were easily oxidized by $\mathrm{H}_{2} \mathrm{O}_{2}$ or $\mathrm{O}_{3}$ [34,35]. These active species attack the central $\mathrm{C}=\mathrm{C}$ double bond of indigo carmine, and greatly contribute to the dye removal process in the discharge reactor $[25,36]$. Mainly, $\mathrm{OH}^{\bullet}$ radicals can be formed at the air-water interface, or directly at the water surface, during discharge propagation. Further $\mathrm{OH}^{\bullet}$ radicals could be produced from the decomposition of $\mathrm{H}_{2} \mathrm{O}_{2}$ in water by UV light emitted from filamentary streamer branches. We observed that UV light intensity was higher at increased input voltage amplitudes. Previous studies have proven that the combination of $\mathrm{UV}$ and $\mathrm{H}_{2} \mathrm{O}_{2}$ resulted in formation of highly reactive $\mathrm{OH}^{\bullet}$ radicals in sufficient amounts, and that the decoloration of the indigo carmine dye occurred much more rapidly with increased $\mathrm{H}_{2} \mathrm{O}_{2}$ concentration $[34,35]$. It has been confirmed that ozone generation in air was increased by discharge pulse voltage, and caused removal of indigo carmine from the water [32,36,37]. In our system, ozone $\left(\mathrm{O}_{3}\right)$ is possibly generated in air, or at air-water interfaces. The subsequent diffusion of $\mathrm{O}_{3}$ to water and contact with discharge plasma assists in further decoloration processes. Thus, chemical processes by water surface discharge are enhanced, compared with direct discharge in water [4]. The absorption spectra of the dye solution also increased at wavelengths of $250 \mathrm{~nm}$, and decreased at $290 \mathrm{~nm}$ with treatment time. The intermediate product is suggested to be aldehyde or ketone, due to break down of the $\mathrm{C}=\mathrm{C}$ double bond [34,37]. 
The decoloration percentage of the indigo carmine dye solution with the treatment time is shown in Figure 10. The decoloration percentage (DP) at $610 \mathrm{~nm}$ wavelength was calculated using the following formula:

$$
D P(\%)=\frac{D_{0}-D_{i}}{D_{0}} \times 100
$$

where $D_{0}$ is the absorbance peak of the initial solution and $D_{i}$ is the absorbance peak of treated solution.

Figure 10 shows that $98 \%$ decoloration was achieved for the applied voltage of $21.6 \mathrm{kV}$, after $6 \mathrm{~min}$ of treatment. Other decoloration percentages were $40.11 \%, 52.99 \%, 65.16 \%$, and $99.8 \%$ for applied voltages of $9.1 \mathrm{kV}, 11.5 \mathrm{kV}, 14.0 \mathrm{kV}$, and $16.5 \mathrm{kV}$, after 7.5 min of treatment. Dye decoloration can be achieved much more rapidly by increasing the voltage amplitude, which would be important in reducing the treatment time for a large-scale application.

The result partially agreed with the results of $\mathrm{H}_{2} \mathrm{O}_{2}$ production discussed above. The higher decoloration percentage indicated higher plasma chemical activity, or more active species formation. On the other hand, for low voltage amplitudes, the amounts of active species were lower, due to the small volume of discharge at the water surface. In addition, electron energy from the H.V. electrode was also possibly low. Thus, chemical reactions were too weak to completely break the $\mathrm{C}=\mathrm{C}$ double bond.

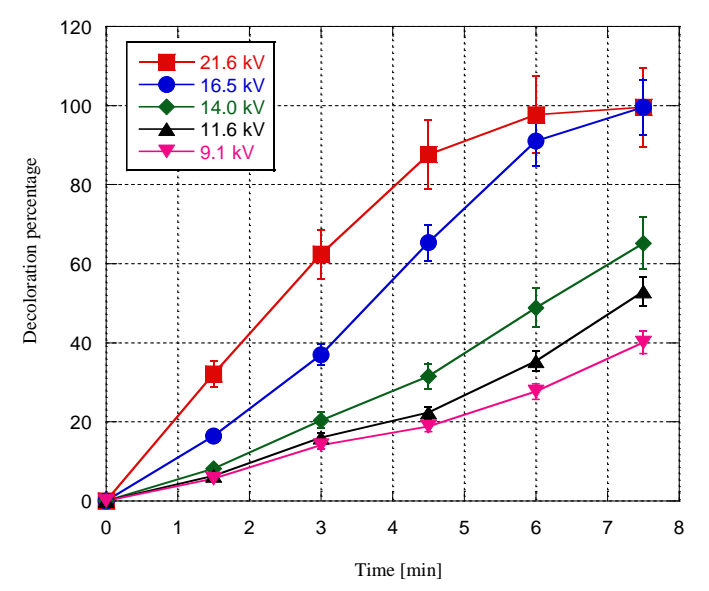

Figure 10. Decoloration percentage of indigo carmine dye solution at different input voltage of streamer discharge at the water surface.

The energy efficiency of dye decoloration for a specific decoloration percentage can be calculated as:

$$
E_{\text {efficiency }}=\frac{D R * V * Q}{E_{P} * N_{P}} * 3.6 E 06[\mathrm{~g} / \mathrm{kWh}]
$$

where, $D R$ is decoloration percentage (Figure 10), $V$ is treated volume of dye solution (L), $Q$ is the Indigo carmine dye concentration $(\mathrm{g} / \mathrm{L}), E_{P}$ is consumed energy per pulse $\left(\mathrm{J} /\right.$ pulse), and $N_{P}$ is total number of pulses (treatment time (s) multiplied by $500 \mathrm{~Hz}$ pulse repletion frequency). Figure 11 shows the energy efficiency of $40 \%$ decoloration as a function of applied voltage. The efficiency of decoloration is almost constant $(0.4$ [g/ $/ \mathrm{kWh}])$ for $11.6,14.0$ and $16.5 \mathrm{kV}$ voltage amplitudes, and increased to 0.485 [g/kWh] for $21.6 \mathrm{kV}$. This can contribute to a higher production of $\mathrm{H}_{2} \mathrm{O}_{2}$ at the higher applied voltage $(21.6 \mathrm{kV})$. On the other hand, the decoloration efficiency is highest at $9.1 \mathrm{kV}(0.65[\mathrm{~g} / \mathrm{kWh}])$, which might be related to the dissociation of $\mathrm{H}_{2} \mathrm{O}_{2}$, as it would be lower due to the low heating effect of the energy discharge, or the experimental artifact. During dye decoloration, the $\mathrm{pH}$ of the discharged dye solution decreased, and its temperature increased with an increase in the applied voltage and pulse numbers (time). As the dye UV absorption spectra can be $\mathrm{pH}$ dependent, and the signals for different breakdown products can overlap, it may not accurately determine the breakdown products. Therefore, Figure 11 gives a preliminary evaluation of the energy efficacy for dye decoloration. 


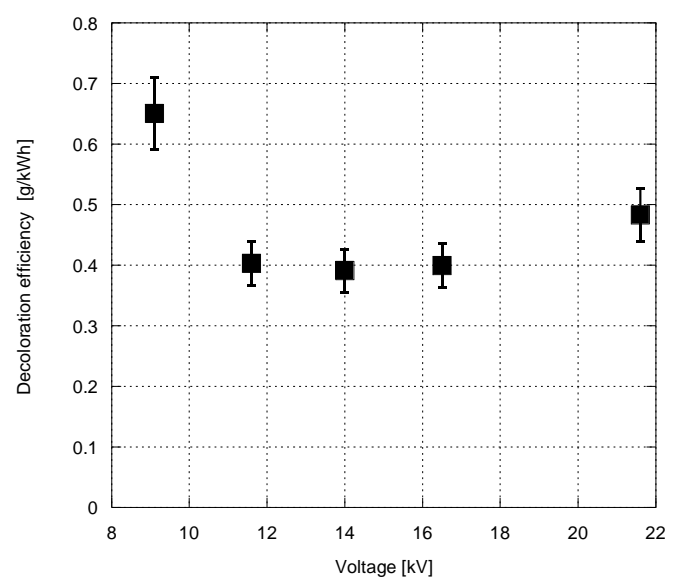

Figure 11. Energy efficiency of $40 \%$ decoloration of indigo carmine dye at different applied voltage amplitudes of water surface streamer discharge.

\section{Conclusions}

The results show that voltage amplitude is an important parameter, which can influence both the streamer discharge at the water surface, and the chemical processes in reactor. To generate different pulse voltages as the output of the PPM system, the V-program of the control unit was varied to set variable resistance at $50-100 \%$. Therefore, increasing the applied voltage amplitude shortened the corresponding pulse width. Experimental results showed that the length of the streamer channels, their propagation velocity, and light emission were increased significantly at the water surface, due to an increase of pulse voltage. The concentration and production yield efficiencies of $\mathrm{H}_{2} \mathrm{O}_{2}$ were significantly higher at $21.6 \mathrm{kV}$, and constantly increased with applied voltages $(9.1,11.6$, 14.0 , and $16.5 \mathrm{kV}$ ). Accordingly, the generation of other active species might well be promoted with increased voltage amplitude. The treatment of indigo carmine results showed that the dye solution was decolorized by $98 \%$ at $21.6 \mathrm{kV}$, while the value was only $28 \%$ at $9.1 \mathrm{kV}$. This indicated the occurrence of strong chemical processes in the reactor through the water surface discharge under high applied voltages, which would be important for the removal of organic pollutants from water.

Author Contributions: All authors conceived and designed the experiments; R.R. and H.H. performed the experiments; R.R. and H.H. analyzed the data; All authors contributed reagents/materials/analysis tools; R.R. and H.H. wrote the paper.

Acknowledgments: The authors acknowledge K. Yoshihara and H. Nagaoka for their help with experiments. This work was supported in part by Grant-in-Aid for Scientific Research from the Ministry of Education, Culture, Sports, Science and Technology of Japan (17K06163).

Conflicts of Interest: The authors declare no conflict of interest.

\section{References}

1. Akiyama, H.; Sakai, S.; Sakugawa, T.; Nakihira, T. Environmental applications of repetitive pulsed power. IEEE Trans. Dielectr. Electr. Insul. 2007, 14, 825-833. [CrossRef]

2. Akiyama, H. Streamer discharges in liquids and their applications. IEEE Trans. Dielectr. Electr. Insul. 2000, 7, 646-653. [CrossRef]

3. Lukes, P.; Locke, B.R. Plasmachemical oxidation processes in a hybrid gas-liquid electrical discharge reactor. J. Phys. D Appl. Phys. 2005, 38, 4074-4081. [CrossRef]

4. Sato, M.; Tokutake, T.; Ohshima, T.; Sugirato, A.T. Aqueous phenol decomposition by pulsed discharge on the water surface. IEEE Trans. Ind. Appl. 2008, 44, 1397-1402. [CrossRef]

5. Locke, B.R.; Sato, M.; Sunka, P.; Hoffmann, M.R.; Chang, J.-S. Electrohydraulic discharge and nonthermal plasma for water treatment. Ind. Eng. Chem. Res. 2006, 45, 882-905. [CrossRef] 
6. Sahni, M.; Locke, B.R. Degradation of chemical warfare agent simulants using gas-liquid pulsed streamer discharges. J. Hazard. Mater. 2006, 137, 1025-1034. [CrossRef] [PubMed]

7. Lukes, P.; Appleton, A.T.; Locke, B.R. Hydrogen peroxide and ozone formation in hybrid gas-liquid electrical discharge reactors. IEEE Trans. Ind. Appl. 2004, 40, 60-67. [CrossRef]

8. Sun, B.; Sato, M.; Clements, J.S. Optical study of active species produced by a pulsed streamer corona discharges in water. J. Electrostat. 1997, 39, 189-202. [CrossRef]

9. Zhang, R.; Zhang, X.; Ma, W.; Xu, Y.; Wang, L.; Guan, Z. Formation of active species by bipolar pulsed discharge in water. IEEE Trans. Plasma Sci. 2012, 40, 2360-2365. [CrossRef]

10. Li, S.; Hu, S.; Zhang, H. Formation of hydroxyl radicals and hydrogen peroxide by a novel nanosecond pulsed plasma power in water. IEEE Trans. Plasma Sci. 2012, 40, 63-67. [CrossRef]

11. Namihira, T.; Sakai, S.; Yamaguchi, T.; Yamamoto, K.; Yamada, C.; Kiyan, T.; Sakugawa, T.; Katsuki, S.; Akiyama, $\mathrm{H}$. Electron temperature and electron density of underwater pulsed discharge plasma produced by solid-state pulsed power generator. IEEE Trans. Plasma Sci. 2007, 35, 614-618. [CrossRef]

12. Joshi, A.A.; Locke, B.R.; Arce, P.; Finney, W.C. Formation of hydroxyl radicals, hydrogen peroxide and aqueous electrons by pulsed streamer corona discharge in aqueous solution. J. Hazard. Mater. 1995, 41, 3-30. [CrossRef]

13. Ono, R.; Oda, T. OH radical measurement in a pulsed arc discharge plasma observed by a LIF metho. IEEE Trans. Ind. Appl. 2001, 37, 709-714. [CrossRef]

14. Sano, N.; Yamamoto, D.; Kanki, T. Decomposition of phenol in water by a cylindrical wetted-wall reactor using direct contact of gas corona discharge. Ind. Eng. Chem. Res. 2003, 42, 5423-5428. [CrossRef]

15. Kawano, S.; Wada, K.; Kakuta, T.; Takaki, T.; Satta, N.; Takahashi, K. Influence of pulse width on decolorization efficiency of organic dye by discharge inside bubble in water. J. Phys. Conf. Ser. 2007, 441, 012007. [CrossRef]

16. Yano, T.; Shimomura, N.; Uchiyama, I.; Fukawa, F.; Teranishi, K.; Akiyama, H. Decolorization of indigo carmine solution using nanosecond pulsed power. IEEE Trans. Dielectr. Electr. Insul. 2009, 16, 1081-1087. [CrossRef]

17. Yan, J.H.; Liu, Y.N.; Bo, Z.; Li, X.D.; Cen, K.F. Degradation of gas-liquid glidding arc discharge on acid orange II. J. Hazard. Mater. 2008, 157, 441-447. [CrossRef] [PubMed]

18. Willberg, D.M.; Lang, P.S.; Hochemer, R.H.; Kratel, A.; Hoffmann, M.R. Degradation of 4-chlorophenol, 3,4-dichloroaniline, and 2,4,6-trinitrotoluene in an electrohydraulic discharge reactor. Environ. Sci. Technol. 1996, 30, 2526-2534. [CrossRef]

19. Zhang, Y.; Zhou, M.; Lei, L. Degradation of 4-chlorophenol in different gas-liquid electrical discharge reactors. Chem. Eng. J. 2007, 132, 325-333. [CrossRef]

20. Sugiarto, A.T.; Ito, S.; Oshima, T.; Sato, M.; Skalny, J.D. Oxidative decoloration of dyes by pulsed discharge plasma in water. J. Electrostat. 2003, 58, 135-145. [CrossRef]

21. Magureanu, M.; Piroi, D.; Gherendi, F.; Mandache, N.B.; Parvulescu, V. Decomposition of methylene blue in water by corona discharges. Plasma Chem. Plasma Process. 2008, 28, 677-688. [CrossRef]

22. Shahni, M.; Locke, B.R. Quantification of hydroxyl radicals produced in aqueous phase pulsed electrical discharge reactors. Ind. Eng. Chem. Res. 2006, 45, 5819-5825. [CrossRef]

23. Vautier, M.; Guillard, C.; Herrmann, J.M. Photocatalytic degradation of dyes in water: Case study of indigo and indigo carmine. J. Catal. 2001, 201, 46-59. [CrossRef]

24. Shimizu, K.; Muramatsu, S.; Sonoda, T.; Blajan, M. Water treatment by low voltage discharge in water. Int. J. Plasma Environ. Sci. Technol. 2010, 4, 58-64.

25. Samaranayake, W.J.M.; Miyahara, Y.; Namihira, T.; Katsuki, S.; Sakugawa, T.; Hackam, R.; Akiyama, H. Pulsed streamer discharge characteristics of ozone production. IEEE Trans. Dielectr. Electr. Insul. 2000, 7, 254-260. [CrossRef]

26. Hackam, R.; Akiyama, H. Air pollution control by electrical discharges. IEEE Trans. Dielectr. Electr. Insul. 2000, 7, 654-683. [CrossRef]

27. Xue, J.; Chen, L.; Wang, H. Degradation mechanism of Alizarin red in hybrid gas-liquid phase dielectric barrier discharge plasmas: Experimental and theoretical examination. Chem. Eng. J. 2008, 138, 120-127. [CrossRef]

28. Aoki, N.; Sakugawa, T.; Akiyama, H.; Akiyama, M. Hydrogen peroxide generation by pulsed discharge in bubbling water. IEEJ Trans. Fundam. Mater. 2013, 133, 636-641. 
29. Akishev, Y.; Aponin, G.; Balakirev, A.; Grushin, M.; Petryakov, A.; Karal'nik, V.; Trushkin, N. Stepwise expansion of a surface dielectric barrier discharge as a result of alternation in formation of streamers and leaders. J. Phys. D Appl. Phys. 2013, 46, 135204. [CrossRef]

30. Miyahara, T.; Oizumi, M.; Nakatani, T.; Sato, T. Effect of voltage polarity on oxidation-reduction potential by plasma in water. AIP Adv. 2014, 4, 047115. [CrossRef]

31. Beroual, A.; Zahn, M.; Badent, A.; Kist, K.; Schwabe, A.J.; Yamashita, H.; Yamazawa, K.; Danikas, M.; Chadband, W.G.; Torshin, Y. Propagation and structure of streamers in liquid dielectrics. IEEE Electr. Insul. Mag. 2009, 14, 6-17. [CrossRef]

32. Katsuki, S.; Akiyama, H.; Abou-Ghazala, A.; Schoenbach, K.H. Paraller streamer discharges between wire and plane electrode in water. IEEE Trans. Dielectr. Electr. Insul. 2002, 9, 498-506. [CrossRef]

33. Dalmazio, I.; Urzedo, A.P.F.M.; Alves, T.M.A.; Catharino, R.R.; Eberlin, M.N.; Nascentes, C.C.; Augusti, R. Electrospray ionization mass spectrometry monitoring of indigo carmine degradation by advanced oxidation processes. J. Mass Spectrom. 2007, 42, 1273-1278. [CrossRef] [PubMed]

34. Ruo-bing, Z.; Yan, W.; Ning-hui, W.; Jie, L. Plasma induced degradation of indigo carmine by bipolar pulsed dielectric barrier discharge (DBD) in the water-air mixture. J. Environ. Sci. 2004, 16, 808-812.

35. Selma, M.; Takashima, K. Decolorization of indigo carmine dye by spark discharge in water. Int. J. Plasma Environ. Sci. Technol. 2008, 2, 56-66.

36. Machmudah, S.; Goto, M. Pulsed Discharge Plasma over a Water Surface Induces Decoloration of Dyes. J. Phys. Conf. Ser. 2013, 441, 012008. [CrossRef]

37. Fartode, A.P.; Parwate, D.V. UV photocatalytic decolorization study of synthetic waste water containing indigo carmine dye in presence of $\mathrm{H}_{2} \mathrm{O}_{2}$. Int. J. Chem. Phys. 2014, 3, 22-31.

(C) 2018 by the authors. Licensee MDPI, Basel, Switzerland. This article is an open access article distributed under the terms and conditions of the Creative Commons Attribution (CC BY) license (http:/ / creativecommons.org/licenses/by/4.0/). 